\title{
Potential of Agroforestry System on Peat Land to Enhance Food Security and Environmental Sustainability
}

\author{
Wahida Annisa ${ }^{1, *}$, Ani Susilawati ${ }^{1}$, Arifin Fahmi $^{1}$, Husna $^{2}$, Dedi Nursyam si $^{3}$ \\ ${ }^{1}$ Indonesian swampland agricultural research institute (ISARI), South Kalimantan \\ ${ }^{2}$ Indonesian Centre for Agricultural Land Resource Research Development (ICALRD), West Java \\ ${ }^{3}$ Agricultural Human Resources Extension and Development Agency (AHREDA), Jakarta
}

\begin{abstract}
Indonesia is a country with the largest tropical peatlands in the world. utilization of peatlands has been widely associated with fires and environmental issues like carbon dioxide emissions because of the highest land-use. The reduction or loss of the peat forest ecosystem for the development of dry land plants on a massive scale has reduced the quality of the environment, so that the function and benefits of the peat ecosystem as a hydrological buffer for the surrounding area are disturbed. This paper aims to synthesize all research results qualitatively to explore the potential for developing agroforestry systems on peatlands in an effort to increase food security and protect the environment. This review paper uses the Qualitative Review Systematics method with stages: 1) formulation of questions, 2) literature search, 3) screening and selecting appropriate research articles, 4) analyzing and synthesizing qualitative findings, 5) presenting finding. Agroforestry has the potential to have a real impact on food security, climate change including mitigation and adaptation, and preserving the environment. Some research results show that the agroforestry systems can be an effective buffer in peatlands in fire control because the peat stabilization process requires control materials to maintain the elemental composition, carboxyl $(\mathrm{COOH})$ and $\mathrm{OH}$-phenol functional groups, so that the peat conditions become stable.
\end{abstract}

Key words: tropical peat, fires, greenhouse gas emissions, buffering capacity, alley cropping

\section{Introduction}

Indonesia is the fourth country that has the largest tropical peatlands in the world after Canada, Russia and the USA (Immirzi and Maltby, 1992). Peatlands have both an economic and ecological role. The role of peatlands from an economic and ecological perspective. From an econom ic point of view, peatlands are important to the community and serve as an important source of livelihood. This is because peatlands provide resources that are used directly, including construction wood such as Gelam Wood, raw materials for weaving such as purun grass, herbaceous plants for consumption and medicine and fish as a source of protein (Suyanto et al. 2003). Meanwhile, the role of peat from an ecological point of view is: (1) as a very large carbon store. At least $25 \%$ of terrestrial $\mathrm{C}$ is contained in peatland which is much larger than in primary forest. This is the reason why peat is said to control the global climate; (2) as a hydrological buffer. The hydrological unit forms the basis for the designation of peat as a conservation zone (dome), buffer zone and use zone; (3) Biodiversity habitat because there a re a number of endemic species that can only grow in the peat ecosystem (Ministry of environment, 2012).

Damage to the function of the peat ecosystem occurs as a result of wrong land management by selecting commodities that are not in accordance with the characteristics of the peatlands. This is exacerbated by the dra ining of peat water which results in dry (irreversible drying) of the peat itself which is currently the trigger for fires. The

\footnotetext{
*Corresponding author: wahidaannisa@pertanian.go.id, annisa balittra@yahoo.com
} 
fact in the field shows that fires that occur almost every year with an increasing area are the fact that peat is no longer in its natural condition or has been damaged. Initially the community used this land for rubber or coconut plantations. In line with the transmigration settlement expansion program in the $80 \mathrm{~s}$, on a large scale peatlands were cleared for food crop a griculture and the largest occurred in Kalimantan in a million hectare paddy field project, but there wa still a lack of understanding of peat characteristics and ecologicalprinciples as well as a lack of stakeholder participation. causing many mistakes in the management of peatlands in Indonesia.

Susta inable and environmentally friendly peatland development must pay attention to specific characteristics both in vertical and horizontal dimensions in one cross-sectoral coordinated institution, supported by firm and comprehensive policies and regulations referring to localwisdom, the use of specific technology and can be applied accordingly. with the carrying capacity of peatlands while still paying attention to the aspects of land conservation and adaptive commodity selection (Ministry of environment, 2012). The concept of using swamps should be in the form of a designation change without having to change the raw function.

In the tropics, climate change causes the greatest loss in the agricultural sector (food a vailability) because it has a direct impact on changes in biophysical and land resources (availability of water and fertilizers and pest control) which affects the production of crops both food and non-food crops (Hairiah et al. al. 2013). The a groforestry pattem conservation a gricultural system is one of the land management systems that can be offered to overcome problems arising from land use change (Sardjono, Djogo, Arifin, \& Wijayanto, 2003). Agroforestry places more emphasis on soil physicalproperties, soil chemistry and nutrient content and its relationship with the environment (Darmayanti, 2012; Jamnadass et a1.2011). Perennial crops (perennials) can change the microclimate for food crops such as sweet potatoes so that growth is good (Maliki et al. 2012). The combination of perennial crops (trees) with food crops in agroforestry systems supports nutrition, production stability, and farmer incomes due to increa sed yields (Susila et al. 2012).

The pattern of annualcrop a groforestry which is planted together with pamgan plants that grow spontaneously but are maintained, grow together has been part of the landscape since the 1970s on the fringes of peatlands on the east coast of Sumatra, Jambi Province. Agroforestry on peat was developed as a combination of coffee, coconut, areca nut and, to a lesser extent, rubber, jelutong and pineapple (Figure 1). This practice has proven to be an effective buffer a ga inst fire incidents, on peatlands (Sakuntala dewi and Wibowo 2016, Dewi et al. 2015). Insusanty, M et al. (2017) reported that agroforestry model with Rubber-Gaharu-Durian at Kampar Regency in Riau Province has a biomass of 135.35 tons/ha and carbon potential of $62.26 \mathrm{C}$ tons/ha while the Rubber-Durian model has a biomass of 82.14 tons/ha and carbon 37.78 tons/ha. The biomass of the Karet-Gaharu model is 93.70 tons/ha with a carbon potential of 43.10 tons/ha.

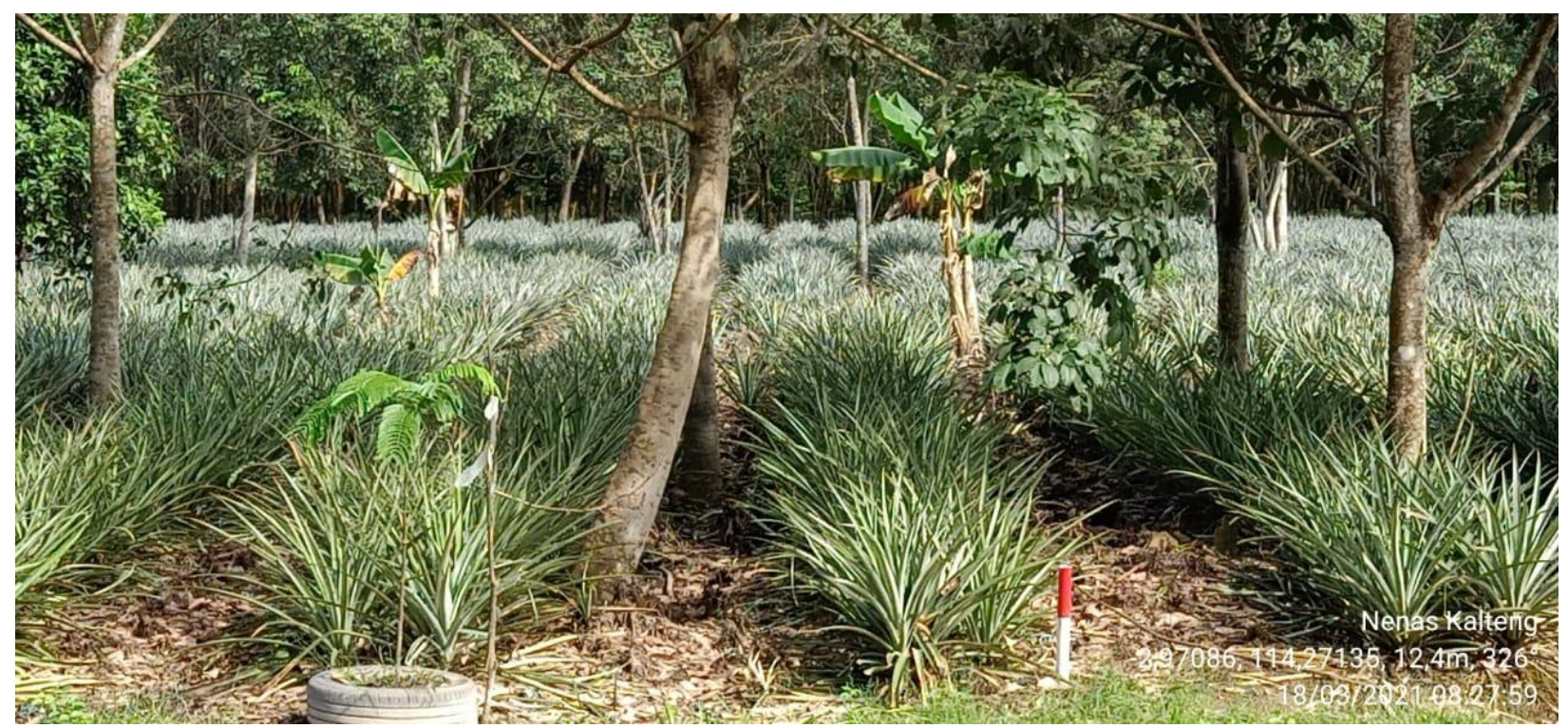

Source: doc wahida annisa, isari 2021.

Fig. 1. A combination of rubber and pineapple agroforestry systems on peatlands of Central Kalimantan

The development of agroforestry systems on peatlands can serve as management practices to bridge the production and protection functions of peat and crea te a daptive co-management stra tegies towards susta inable and 
integrated management. This paper aims to synthesize all research results qualitatively to explore the potential for developing agroforestry systems on peatlands in an effort to increase food security and protect the environment.

\section{Methodology}

This review paper uses the Qualitative Review Systematics method (Francis \& Baldesarimethod, 2006). The stages of the method used are: 1) formulation of questions about a groforestry systems on peatlands and their relationship with efforts to increase food security and reduce GHG emissions, 2) search for systematic review (conducting a systematic literature search) 3) screening and selection of suitable research articles with the topic of agroforestry systems on peatlands (screening and selecting appropriate research articles) 4) analysis and synthesis of qua lita tive findings (a nalyzing and synthesizing qua litative findings) 5) Preparing paper(presenting finding).

The approach used in the preparation of this paper is meta aggregation (Lewin, 2008), namely by elaborating several research topics related to a groforestry systems to produce an analytical framework (conceptual framework) supported by the search for relevant research articles to be compared and summarized. In the meta -aggregation approach, the synthesis result is an "aggregate" of various research results according to the theme being studied

Literature sources are all qua litative publications related to the life experiences of patients with foot ulcers via systematic search methods. The synthesis process includes (i) the themes and concepts from the relevant study are extracted, (ii) the results of this extraction are organized into important (main) findings, (iii) the findings are grouped into categories, (iv) the categories are then synthesized become a theme (adjusted to the conceptual framework that is arranged).

\section{Finding}

\subsection{The Concept of Agroforestry in Peatlands}

Peatland management must be considered thoroughly by taking into account hydrological conditions, peat characteristics, land use, land ownership and conservation. The approach method adopted should be based on the objectives of rehabilitation or restoration. For areas that are permitted to have productive functions, they can be developed for agroforestry, paludiculture or a combination of both, while for other areas where the conservation agenda is a high priority, the target is restoration of the peat swam p ecosystem (Figure 2).

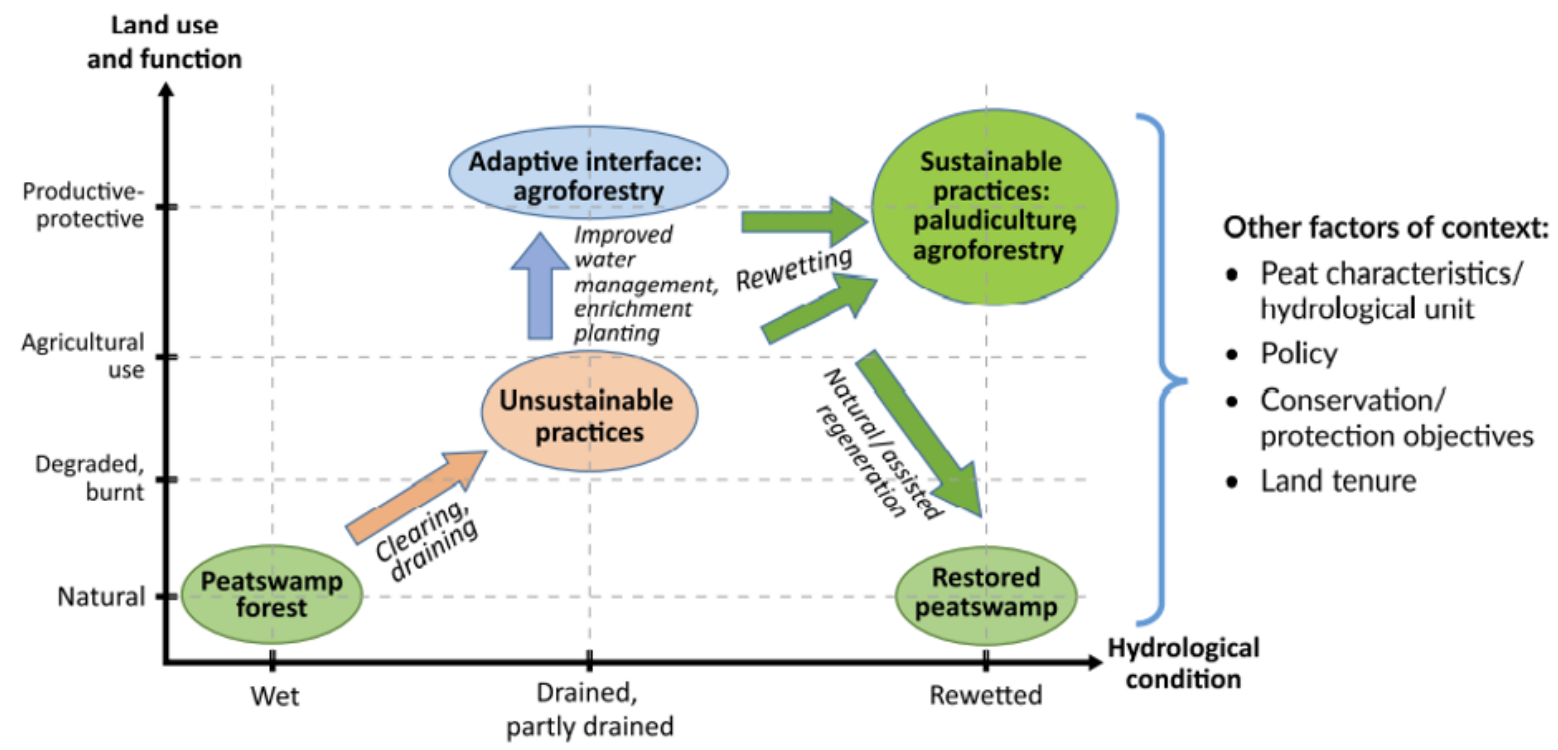

Fig. 2. Peatland Management Approach for Restoration and Rehabilitation (Widayati et al. 2016)

Agroforestry or a groforestry is the planting of various types of annual crops with / without sea sonalcrops, with / without livestock on the same plot of land to increase income and environmentalsustainability. This practice is a local livelihood for farmers on peatlands for which their needs have been applied for a long time, while on the other hand drained pea tlands can be saved from further degra dation or fires. For degraded or burned peatlands, the concept 
of a groforestry or agroforestry has multiple functions, in addition to the productive function of peatlands, it can a so protect land from further degradation and excessive drainage (Widayatiet al.2016). This approach is recommended if local livelihoods are to be maintained. In addition, agroforestry is a technique that can be offered for ADAPTATION because it has a buffer aga inst the effects of climate change, including microclimate control (Van Noordwijk, 2013), reducing landslides (Hairiah et al., 2006), surface runoff and erosion as well as reduce nutrient losses through leaching (Widianto et al., 2007; Suprayogo et al., 2002), and maintain soil flora and fauna biodiversity (Dewi et al., 2006).

Several agroforestry practices can be relevant for a variety of agro-ecological zones, and many systems with different compositional ranges can essentially fulfill the same functions for livelihoods and landscapes. So there is no single classification scheme that can be universa lly applied (ImmanuelF Torquebiau, 2000). What differentia tes agroforestry from other land uses is the deliberate inclusion of woody perennials in agriculture, which usually leads to economic and / or ecological intera ctions between timber and non-timber system components (Na ir, P.R., 1993). In most documented ca ses of successful agroforestry establishment, tree-based systems are more productive, more susta inable, and more attuned to people's cultural or m a terial needs than tree-less a lterna tives. However a groforestry is not being adopted everywhere, and better insights are needed for the productive and environmental performance of a groforestry systems.

Table 1. Diversity of agroforestry classification,

\begin{tabular}{|l|l|l|l|}
\hline \multicolumn{1}{|c|}{ Typology of agroforestry } & \multicolumn{1}{|c|}{ Key elements } & \multicolumn{1}{c|}{$\begin{array}{c}\text { Example agroforestry } \\
\text { practices }\end{array}$} & reference \\
\hline Ecological & $\begin{array}{l}\text { Geographical location } \\
\text { (agroforestry system } \\
\text { adaptability to particular } \\
\text { ecologies) }\end{array}$ & $\begin{array}{l}\text { Lowland humid or sub- } \\
\text { humid tropic of agroforestry }\end{array}$ & $\begin{array}{l}\text { Emmanuel F Torquebiau. } \\
(2000) ; \text { Nair (1993) }\end{array}$ \\
\hline Physiognomy & $\begin{array}{l}\text { Parkland, mosaic and } \\
\text { multistoried homegarden }\end{array}$ & $\begin{array}{l}\text { Feidherbia, shea butter parks } \\
\text { in west Africa, long term } \\
\text { fallows }\end{array}$ & Garrity, D.P et al. (2010) \\
\hline Compositional & $\begin{array}{l}\text { Simultaneous or sequential } \\
\text { combination of trees, crop } \\
\text { and animal }\end{array}$ & $\begin{array}{l}\text { Trees in pasture and } \\
\text { silvopastoral and } \\
\text { agrosilvopastural }\end{array}$ & Nguyen, Q. et al. (2013) \\
Practices (Systems) & $\begin{array}{l}\text { Management systems, } \\
\text { livehood strategies }\end{array}$ & $\begin{array}{l}\text { flley cropping, long term } \\
\text { multilayer tree cropping, } \\
\text { woodlots }\end{array}$ & $\begin{array}{l}\text { Emmanuel F Torquebiau. } \\
\text { (2000); Nair (1993) }\end{array}$ \\
\hline Functional & Soil fertility & $\begin{array}{l}\text { Conservation and boundrary } \\
\text { planting }\end{array}$ & Bayala J et al. (2011) \\
\hline Socioeconomic & $\begin{array}{l}\text { Scale of production and } \\
\text { level of technology, input } \\
\text { and management }\end{array}$ & $\begin{array}{l}\text { Low input, high input } \\
\text { agroforestry }\end{array}$ & $\begin{array}{l}\text { Sood KK et al. (2011); } \\
\text { Assogbadjo AE et al. (2012) }\end{array}$ \\
\hline
\end{tabular}

Source: Cheikh Mbow et al. (2014)

The application of the concept of agroforestry in peatlands must be locally specific by considering environmental characteristics, social, economic, cultural, traditional and wisdom aspects of local communities as well as trade-offs faced by farmers in determining land use practices. Common agroforestry patterns found in peatlands are alley cropping (pineapples are planted together with rubber plants using a tunnel system), trees along borders (pineapples are surrounded by woody and secondary crops such as rubber, cassava and banana) and mix (pineapple mixed with plants). timber, such as rubber, fruit trees and secondary crops This agroforestry system can contribute to an increase in household income by $41.32 \%$ with absorption of labor of 2.39 people per ha.

\subsection{Agroforestry and Climate Change on Peatlands}

The rate of deforestation in Indonesia in the two decades, 1990-2000 and 2000-2010, respectively reached 1.82 million ha / yearand 1.02 million ha / year. This incident contributed significantly to the size of nationalemissions. The application of agroforestry systems on peatlands is a solution to mitigating the accumulation of GHG in the atmosphere (IPCC, 2000), because the trees planted by farmers a re not only economically benefic ial but a lso provide ecological value. The carbon content of each agroforestry model varies based on the type and composition of its constituents (Insusanty et a 1. 2017). Ha iriah and Rahayu (2007) sta te that the potential for carbon mass can be seen from the biomass of the existing stands. $\mathrm{CO} 2$ gas as one of the largest constituents of GHG in the air is absorbed by 
trees and understorey for photosynthesis, and is stored as C-organic in plant bodies (biomass) and soil for a long time, reaching 30-50 years. Nair (2012) reported that the amount of $\mathrm{C}$ in the subsoil in the agroforestry system was greater than that in sea sonalcrops.

The relatively high carbon storage in peatlands is an indicator of the high potential of this ecosystem to contribute to greenhouse gas emissions, if the peat experiences decomposition or fires. Emissions and carbon sequestration in peatlands occur simultaneously and depend on natural conditions and human intervention. Carbon emission is faster than tethering in a erobic conditions where the surface layer is unsaturated, so that microorganism activity is optimal. Meanwhile, in ana erobic conditions (water saturation), carbon tethering (sequestration) takes place faster than decomposition. Reclamation of peat swamp forest into agricultural land changes the role of peat as a carbon sink into a carbon producer or a source of GHG emissions. Globally, in the last 18 years, the amount of CO2 emissions from peatlands drained from 1,058 Mton (in 1990) to 1298 Mton (in 2008). This increase occurred in developing countries, including Indonesia. Hoijer et al. (2006) reported that the amount of CO2 emissions from the decomposition of drained peatlands was $632 \mathrm{Mt} \mathrm{CO} 2$ (interva1355-874 Mt CO2). Agroforestry is often seen as a cost-effective strategy for mitigating climate change. Annual crop (tree) based agricultural systems can store carbon in the soil and in woody biomass, thereby reducing greenhouse gas emissions from the soil (Verchot, L.V et al. 2007). The framework in which agroforestry can contribute to climate change that affects the successful implementation of an agroforestry system is shown in Figure 3. The level of carbon storage between fields varies, depending on the diversity of species and plant densities present, soil types and management (Mutuo et al., 2005; Hairiah et al., 2011, Hairiah et al. 2013). Therefore, to extrapolate C reserves in the land use system Mutuo et al. (2005) reported that in the tropics a groforestry systems can absorb (sequestration) of $\mathrm{C}$ and store it in plant biomass an a vera ge of about $70 \mathrm{Mg} \mathrm{ha}^{-1}$, in the topsoil about $25 \mathrm{Mg} \mathrm{ha}^{-1}$, and in the lower layer about $20 \mathrm{Mg} \mathrm{ha}^{-1}$.

According to Harja et al., (2012) that the results of carbon calculation using REDD-Abacus SP with two scenarios show that the implementation of agroforestry with carbon stock and low economic value can reduce carbon emissions by $30 \%$ and increa se the economic value of land use by $80 \%$, but if Agroforestry is implemented in places with low carbon stocks and high economic value, it turns out that a grofo restry can reduce emissions (Figure 4). However, the value of these benefits in the field will vary depending on tree production which is influenced by the suitability of tree species to the selected location, land management (types of plants planted) and market demand (Martin et al., 2010).

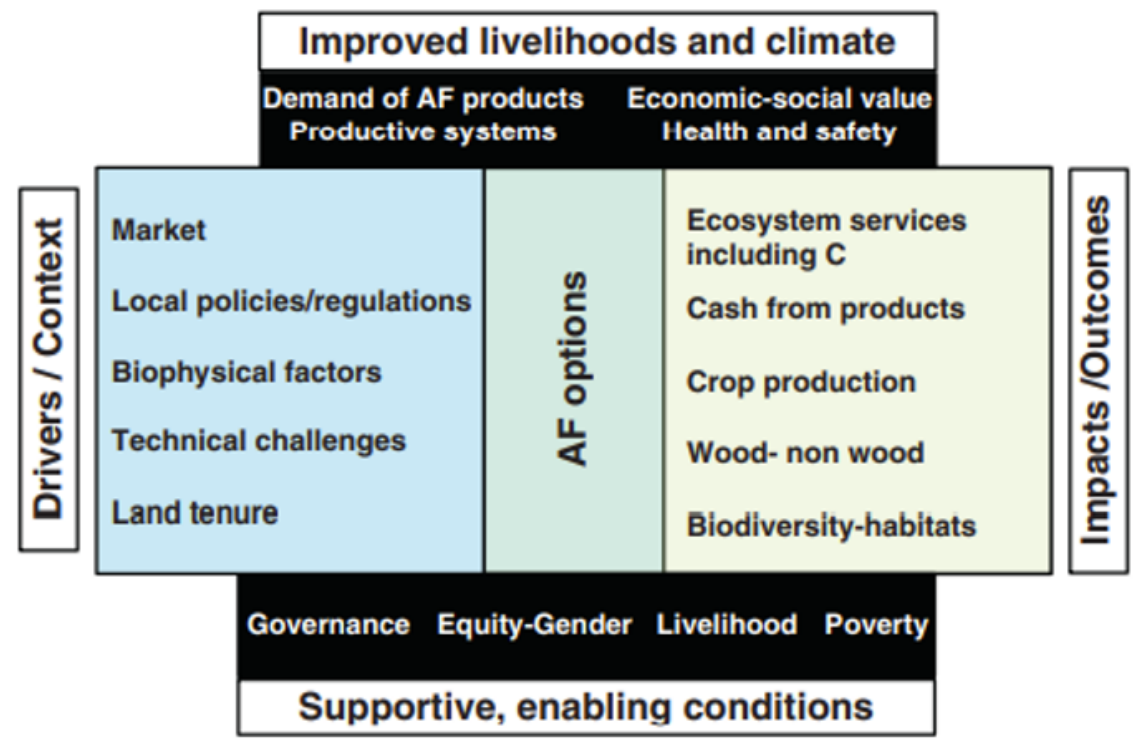

Fig. 3. Framework on the Contribution of Agroforestry to Climate Change (Harja et al. 2012) 


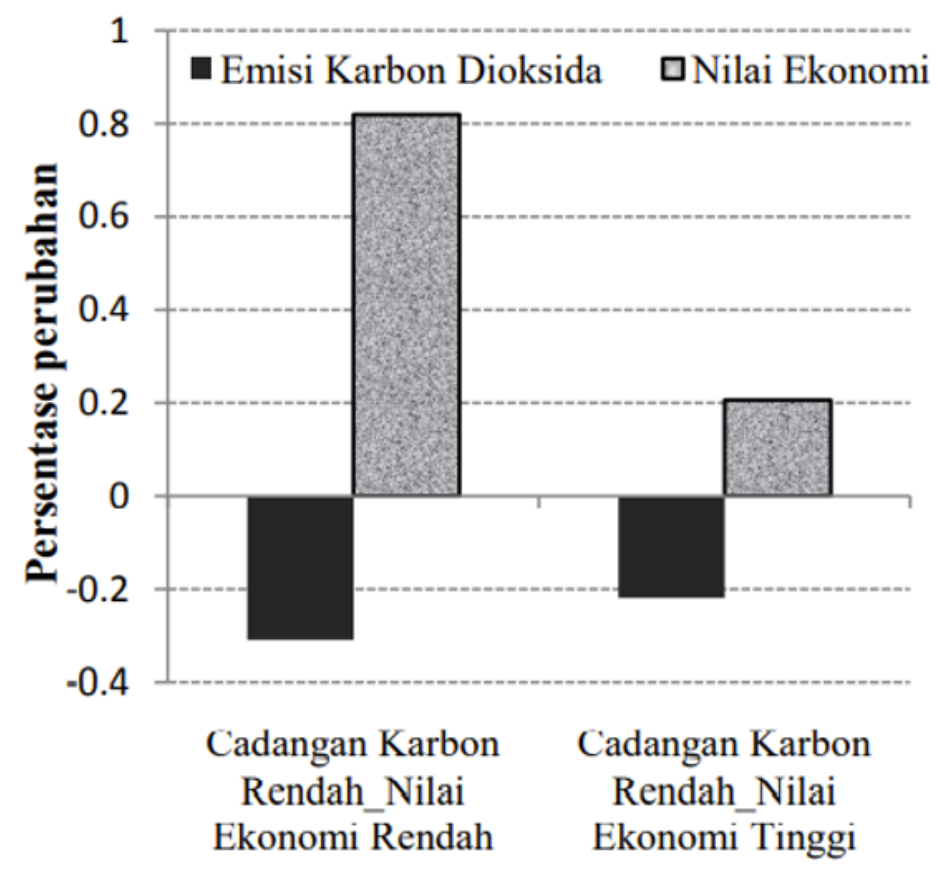

Fig. 4. Carbon stock and economic value in West Tanjung Jabung Regency based on the results of the REDD Abacus SP simulation (Johana et al., 2012)

Agroforestry has the potential to be implemented in locations with moderate extreme climates, especially high tempera tures, as well as annual clima te fluctuations because the presence of tree canopies can create a more a dequate microclimate for crops (DeSouza HN et al. 2012). Although microclimate effects can represent adaptation benefits for farmers, increa se resilience through increased productivity and also contribute to addressing climate change at the farm level. Developing agroforestry on land with low tree cover has been identified as one of the most promising strategies for increasing food production no additional deforestation. In addition to increasing and stabilizing a gricultural income, agroforestry a lso reduces the greater vulnerability to shocks through humans and environmental wealth with adaptation benefits to climatic hazards are not so numerous.

\subsection{Analysis of agroforestry systems on peatland}

A recent paper showed that agroforestry reduced food insecurity during droughts and floods in western Kenya by $25 \%$ due to increased income and improved livelihoods (Thorlakson $\mathrm{T}$ and Neufeldt H, 2012). Agroforestry practices that bridge economic va lue and environmental functions, and offer diversification of commodities to buffer environmental fluctuations and hazards, are economically less profitable because of their limited scale. For peatlands, adopting and mainstreaming agroforestry is a necessity that must be implemented because the environmental risks from fire and greenhouse gas emissions are otherwise very high. Policies and mechanisms that empower and strengthen capacity are prerequisites for environmental restoration and protection, especially where local livelihoods are at stake. Strengthening capacity is very important, especially at the local level, and should also occur along the value chain as part of reducing vulnerability to various uncertainties. This is the key to the sustainability of the pea tland management efforts

The agroforestry pattern that is commonly applied by farmers on peatlands is a combination of forestry components (or woody plants) with agricultural components (alley cropping) using a tunnel system, which has very good prospects for development. Fahruni (2018) reported that planting peanuts as seasonal crops and rubber as perennial crops in agroforestry patterns on peatlands in Central Kalimantan had a positive effect on the growth of staple crops with an increase in the height of rubber plants (Hevea brasiliensis Muell. Arg.) Of $62.78 \%$

The results of the financial analysis of the a groforestry pattern of rubber and food crops in ka la mpangan Central Kalimantan provided a profit of IDR 2,827,000 with an R / C ratio of 2.03 (Fahruni, 2015). Tata et al. (2013) also reported that the results of the analysis of the profitability of rubber agroforestry with food crops provided a profit of $\operatorname{Rp~7,327,000~/~ha,~with~a~labor~requirement~of~} 121$ people / ha / year. In addition, the results of the financial 
analysis of the cultivation of jelutong swamp with a groforestry systems, namely jelutong monoculture and mixed cropping pattern agroforestry with components of jelutong, rubber and rice (planted in the first to third years) to restore degraded peatlands a re economically fea sible (Marinus harun, 2014)

\subsection{Framework development agroforestry system on peat land}

The framework in which agroforestry can contribute to food security, social wealth and climate change requires a clear understanding of the components and processes relevant to the sustainable management of peat ecosystems. Agroforestry is one of the few land use strategies that promise such synergies between food security and climate change mitigation. Policies for the interaction between climate variability (current and future) and food security through agroforestry practices are shown in Fig. 5.

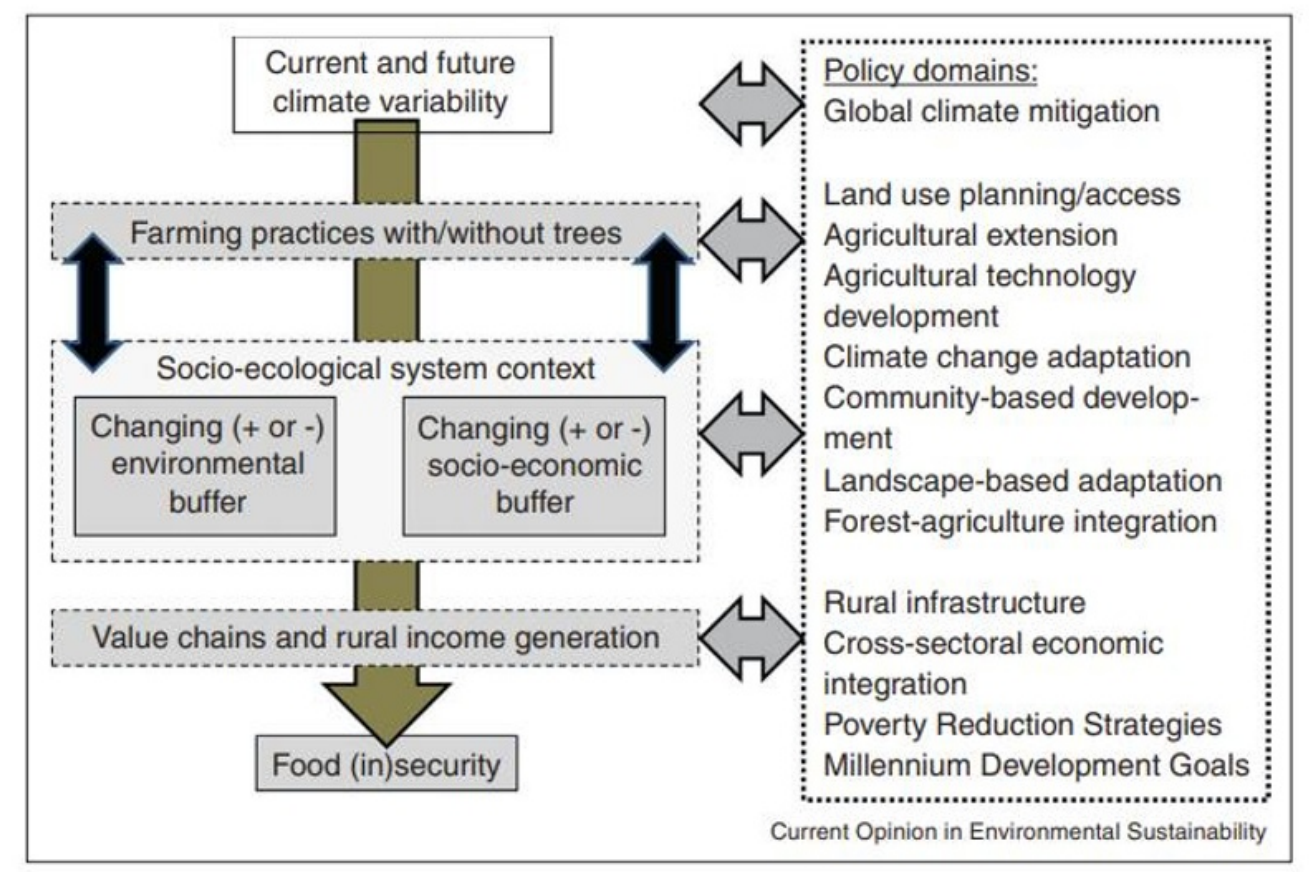

Source: Cheikh Mbow et al. (2014)

Fig. 5. Policy directions for interactions between climate variability and food security in agroforestry systems

At the landscape scale, agroforestry plays an important role in water management and maintains biodiversity and terrestrial carbon stocks (Pagiola et al., 2007). With high production demands, it is often followed by a decre ase in environmental services resulting in a trade off (profitable on the one hand but at the expense of the other). Increased intensification of agricultural systems, including agroforestry, will be followed by an increase in production but followed by a decrease in the level of biodiversity and other environmental services. From the ana lysis of the carbon stock tra de off and land profitability (calculated from the NPV value), it is known that natural forest is a land use with high carbon stock but low economic value. Meanwhile, agroforestry is a land use with high carbon stock even though it is not as high as in naturalforest, but the economic value of a groforestry is relatively higher than forest (Hairiah et al. 2013).

\section{Conclusion}

This paper presents an overview on the potential of agroforestry with special reference to tropical land. Land degradation and crop losses and climate change especially the adverse effects of enhanced atmospheric carbon dioxide levels increases the threat to Asian food security Agroforestry has the potential to have a real impact on food security, climate change including mitigation and adaptation, and preserving the environment. Woody perennial a groforestry systems have the potential to sequester of carb on dioxide and the global warming process. Some research results show that the agroforestry systems can be an effective buffer in peatlands in fire control 
because the peat stabilization process requires control materials to maintain the elemental composition, carboxyl $(\mathrm{COOH})$ and $\mathrm{OH}-$ phenol functional groups, so that the peat conditions become stable.

\section{Reference}

1. Assogbadjo AE, Kakaı” RG, Vodouhe^ FG, Djagoun CAMS, Codjia JTC, Sinsin B: Biodiversity and socioeconomic factors supporting farmers' choice of wild edible trees in the agroforestry systems of Benin (West Africa). Forest Policy Econ 2012, 14:41-49.

2. Bayala J, Ka linganire A, Tchoundjeu Z, Sinclair F, Garrity D: Conservation agriculture with trees in the West African Sahel - a review. World Agroforestry Centre Occasional Paper No. 14. Na irobi; 2011:72

3. Cheikh Mbow, Meine Van Noordwijk, Eike Luedeling, Henry Neufeldt, Peter A Minang and Godwin Kowero. 2014. Agroforestry solutions to address food security and climate change challenges in Africa. Current Opinion in Environmental Sustainability 2014, 6:61-67.

4. Dewi S, van Noordwijk M, Dwiputra A, Tata HL, Ekadinata A, Galudra G, Sakuntaladewi N, Widayati A. 2015. Peat and land clearing fires in Indonesia in 2015: Lessons for polycentric governance. ASB Policy Brief 51. Nairobi, Kenya: ASB Partnership for the Tropical Forest Margins.

5. Darmayanti, A. S. (2012). Beberapa sifat fisika kimia tanah yang berpenga ruh terhadap model kecepatan infiltrasi pada tegakan mahoni,jabon, dan trembesi di Kebun Raya Purwodadi. Jurnal Penelitian Hayati, 17(1), $185-191$.

6. DeSouza HN, DeGoede RGM, Brussaard L, Cardoso IM, Duarte EMG, Fernandes RBA, Gomes LC, Pulleman MM: Protective shade, tree diversity and soil properties in coffee a groforestry systems in the Atlantic Rainforest biome. Agric Ecosyst Environ 2012, 146:179-196

7. EmmanuelF Torquebiau. 2000. A renewed perspective on agroforestry concepts and classification,Comptes Rendus de l'Académie des Sciences - Series III - Sciences de la Vie, Volume 323, Issue 11, Pages 1009-1017,

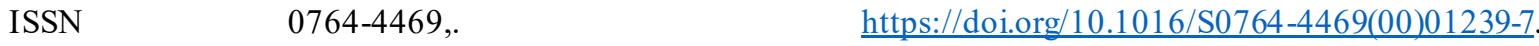
(https://www.sciencedirect.com/science/article/pii/S0764446900012397)

8. Francis C. \& Baldesari (2006). Systematic Reviews of Qualitative Literature. Oxford: UK Cochrane Centre

9. Fahruni. 2015. Analisis Pola Agroforestri Pada Kebun Petani. Jurnal Daun. Jurnal Ilmiah Pertanian dan Kehutanan Universitas Muhamamdiyah, Palangkaraya. Volume 5 Nomor I, Juni

10. Garrity, D.P., Akinnifesi, F.K., Ajayi, O.C. et al. Evergreen Agriculture: a robust approach to susta inable food security in Africa. Food Sec. 2, 197-214 (2010). https://doi.org/10.1007/s12571-010-0070-7

11. Harja D, Dewi S, Van Noordwijk M, Ekadinata A, Rahmanulloh A dan Johana F, 2012 . REDD Abacus SP. Buku Panduan Pengguna dan Software. Bogor, Indonesia. World Agroforestry Centre (ICRAF) Southea st Asia Regional Program. 148 p.

12. Hairiah K, Ekadinata A, Sari R R dan Rahayu S, 2011. Petunjuk praktis Pengukuran karbon tersimpan dihutan dan lahan-lahan Pertanian berbasis pohon. Ekstrapolasi dari tingkat lahan ke tingkat lanskap. World Agroforestry Centre, ICRAF Southeast Asia .

13. IPCC. 2000. Land Use, Land-Use Change and Forestry. A Special Report of the IPCC. Cambridge University Press, Cambridge, UK. 377pp.

14. Jamnadass R H, Dawson I K, Franzel S, Leakey R R B, Mithöfer D, Akinnifesi F K et al. 2011. Improving livelihoods and nutrition in sub-Saharan Africa through the promotion of indigenous and exotic fruit production in smallholders' a groforestry systems: a review. International Forest Review 13:338-354.

15. Kementerian Lingkungan Hidup. 2012. Strategi Nasional. Pengelolaan Lahan Gambut Berkelanjutan di Indonesia. Deputi Bidangpengendalian Kerusakan Lingkungan dan Perubahan Iklim. 50 halaman

16. Martin F S, Lusiana B, Van Noordwijk, 2010. Tree growth prediction in relation to simple set of site quality indicator for six native tree species in the Philippines. Int.J. For.Res. Vol. 2010, Article ID 507392. 10p. DOI: $1155 / 2010 / 507392$

17. Maliki R, Cornet D, Floquet A, Sinsin B. 2012. Agronomic and economic performance of yam -based systems with shrubby and herbaceous legumes a dapted by smallholders. Outlook on Agriculture 41:171-178

18. Nair, P.R., 1993. An introduction to agroforestry. Springer Science \& Business Media

19. Nair P K R. 2011. Agroforestry systems and environmentalquality: Introduction. In: Chang S, Nair V, Kort J and Khasa D (eds.). J. Env. Quality, 40 (3): 784-790. 
20. Nguyen, Q., Hoang, M.H., Öborn, I. et al. Multipurpose a groforestry as a climate change resiliency option for farmers: an example of local adaptation in Vietnam. Climatic Change 117,241-257 (2013). https://doi.org/10.1007/s10584-012-0550-1

21. SakuntaladewiN, Wibowo LR. 2016. The political economy of peat fire in Tanjung Jabung Barat Dictrict. In: Tata HL, Tampubolon AP, eds. 2016. Peat fire risk management. A final report of technical agreement of ICRAF and CCRRD with regard to "Secured Landscape: Sustaining Ecosystem and Carbon Benefits by Unlocking Reversal of Emission Drivers in Landscapes". Bogor, Indonesia: Forest Research and Development Centre. p.5-33.

22. Susila A D, Purwoko B S, Roshetko J M, Palada M C, Kartika J G, Dahlia L et al., eds. 2012. Vegetableagroforestry systems in Indonesia. Bangkok: World Association of Soil and Water Conservation; Nairobi: World Agroforestry Centre.

23. Sardjono, M. A., Djogo, T., Arifin, H. S., \& Wijayanto, N. (2003). Klasifikasi dan pola kombinasikomponen agroforestri: Bahan ajaran agroforestri 2. Bogor: World Agroforestry Centre (ICRAF). Retrieved from https://www.worlda groforestry.org/region/sea/publications/download?dl=/lecturenote/LN000204.pdf\&pubID=76

24. Suprayogo D, Van Noordwijk M, Hairiah K and Cadisch G. 2002. The inherent 'safety -net' of ultisols: Mea suring and modeling retarded leaching of mineral nitrogen. Eur.J.Soil Sci. 53, 185-194.

25. Sood KK, Mitchell CP: Household level domestic fuel consumption and forest resource in relation to a groforestry a doption: evidence a ga inst need-ba sed a pproach. Bioma ss Bioenergy 2011, 35:337-345.

26. Suyanto., U. Chokkalingam., P. Wibowo. 2003. Kebakaran di Laha n Rawa/Gambut di Sumatera: Masalahdan Solusi. Prosiding Semiloka (with English summary). Palembang, Sumatera Selatan 10-11 Desember 2003.

27. Van Noordwijk, M.; Dewi, S.; Leimona, B.; Lusiana, B.; Wulandari, D. 2013. Negotiation-Support Toolkit for Learning Landscapes; World Agroforestry Centre: Bogor, Indonesia. p. 285.

28. Verchot, L.V., Van Noordwijk, M., Kandji, S. et al. Climate change: linking a daptation and mitiga tion through a groforestry. Mitig Adapt Strat Glob Change 12,901-918 (2007). https://doi.org/10.1007/s1 1027-007-9105-6

29. Widayati, Atiek \& Tata, Hesti \& Van Noordwijk, Meine. (2016). Agroforestry on peatlands: combining productive and protective functions as part of restoration.

30. Widianto, Suprayogo D, Lestari I D. 2007. Alih Guna Lahan Hutan Menjadi Lahan Pertanian : Apakah fungsi hidrologis hutan dapat digantikan sistem kopi monokultur? Prosiding Seminar sehari: "Penanganan Bencana Sumber Daya Pertanian”, 1 Februari 2007, Fakultas Pertanian, Universitas Brawijaya, Malang. 